\title{
Characteristics of Effective EFL Instructors: Language Teachers' Perceptions Versus Learners' Perceptions
}

\author{
Negar Hajizadeh (Corresponding author) \\ English Language Department, Tabriz University \\ Tabriz, Iran \\ Tel: 00989141048074 E-mail: negarhajizadeh2012@yahoo.com \\ Neda Salahshour \\ School of Linguistics and Applied Language Studies, Victoria University of Wellington \\ POBOX 6012 Wellington New Zealand \\ Tel: 0064221904324 E-mail: Neda.Salahshour@vuw.ac.nz
}

Received: 24-09-2013

doi:10.7575/aiac.ijalel.v.3n.1p.202
Accepted: 24-11-2013

Published: 01-01-2014

URL: http://dx.doi.org/10.7575/aiac.ijalel.v.3n.1p.202

\begin{abstract}
Improving the field of foreign language teaching without improving the qualities of the teachers seems impossible. This attempt, at first hand, requires recognizing the qualities of effective EFL teachers. The aim of this study was to find what foreign language instructors perceive to be the most important characteristics of a successful EFL teacher. In addition, the teachers' perception was compared to that of learners' to see whether there were discrepancies between the two groups' perceptions regarding the preferable characteristics of an effective English language instructors or not. A 58-item questionnaire was administered to teachers at a prominent language institute in Iran. This questionnaire was divided into eight sections and addressed issues relating to teachers' personal qualities, command in English, teaching methods and evaluation methods they used within the class, mastery over teaching, teacher-student relation, class management and finally language skills management. Teachers were asked to specify the importance of each item in the questionnaire using terms like not important at all, somehow important, important and finally very important. Basic statistics were used to convert the qualitative results into quantitative ones for easier comparison. Interestingly however, the study revealed that the students' perceptions and teachers' perceptions do not differ in major ways although there are slight discrepancies.
\end{abstract}

Keywords: EFL, effective instructors, leaners' perceptions, instructors' perceptions

\section{Introduction}

Without doubt there is a direct relationship between the effectiveness of an instructor and the amount of the learning that goes on in the classroom. Having an effective instructor is a key factor in any field, which provides grounds for enhancing learning. Even if all the other circumstances are met, a low performance on the part of an instructor can minimize the amount of learning dramatically. This fact justifies all the attempts being done by researchers in different fields in general and in ELT in particular to come up with detailed definitions regarding the characteristics of qualified and effective teachers (Borg, 2006; Arikan, Tasher \& Sezgi-Sarac-Suzer, 2008; Babai Shishavan \& Sadeghi, Khojastemehr \& Takrimi, 2009; Ozsevik, Arikan, 2010; Chen, Salahshoor \& Hajizadeh, 2012).

The qualitative nature of 'being effective' has made it difficult to reach a definite list of characteristics of an 'effective' instructor. Also, except for a very few studies, almost all the other studies have focused on either learners' or instructors' perspectives to identify the characteristics of an 'effective' instructor. However, a comparative study of both instructors' and learners' perspectives on this matter remains largely under-investigated. Therefore, the researchers of this study were motivated to conduct a research to investigate the perceptions of both parts, i.e. instructors and learners, on the characteristics of an effective EFL instructor and compare their ideas to identify any similarities and differences. In the following sections, a brief overview will be given of previous studies which address the issue of an effective instructor in general and with a specific focus on ELT teachers. This will be followed by detailed reference to a previous study by Salahshour \& Hajizadeh (2012) which has identified the characteristics deemed necessary for an effective language instructor from the perspective of Iranian English language learners. Salahshour \& Hajizadeh's study will be used to compare the student's perceptions with those attained from the teachers in this study. Finally, the methodology for this research will be elaborated on and a table with the results will be presented. 


\section{Review of the Related Literature}

\subsection{Characteristics of good teachers in general}

The question of what makes a good teacher is hardly a new subject. A brief look at literature reveals several studies on this matter. For example Thompson, Greer, and Greer (2004) explored the reflections of university students regarding the characteristics of their favorite teachers from whom they were able to learn. Data collected from the students indicated that there are twelve common characteristics that emerged as central to what students conceptualize as good teaching. Those twelve characteristics were displaying fairness, having a positive outlook, being prepared, using a personal touch, possessing a sense of humor, possessing creativity, admitting mistakes, being forgiving, respecting students, maintaining high expectations, showing compassion, and developing a sense of belonging for students. They suggested that all those characteristics center around the theme of caring.

Following the first attempts in recognizing the characteristics of effective teachers regardless of what subject matter they are teaching, researchers started to work more specifically. That is, they focused their attempt on recognizing the characteristics of effective teachers of different subject matters one at a time. For example the characteristics of effective language teachers have been the focus of attention in many studies. Some researchers believe that it is the nature of the subject matter that makes language teachers different from teachers of other fields (Hammadou \& Bernhar, 1987; cited in Babai Shishavan, 2009, p.130). In the following section previous studies which have focused specifically on EFL teachers will be expounded upon.

\subsection{Characteristics of 'effective' EFL instructors}

It cannot be denied that in developing countries, apart from recent attempts in some English classes, almost all other classes are still run by traditional teaching methods in which learners are not more than receivers of knowledge. However, the new era of English language teaching, especially after the emergence of Communicative Language Teaching with its focus on equipping the learners with the ability to communicate efficiently in English demands that classes be learner-centred and be less structure-centred. Most private English institutions have been trying to move away from traditional language teaching methods to advance toward complete learner-centered classes, but unfortunately the outcomes are in vain. Recently, attempts have been made in different parts of the world in search for learners' perceptions of characteristics of effective EFL instructors to meet their expectations regarding ideal instructors and to implement curricular changes based on what they really expect to receive in class.

The fact of the matter is that in EFL environments English class is the prominent, if not the only, true opportunity to 'learn' and 'use' English. This fact highlights the importance of the EFL teacher as the prominent 'source of input' for the learners. Therefore having an 'effective' teacher is the fundamental need of an EFL class 'for efficient functioning of educational systems and for enhancing the quality of learning' (Babai Shishavan \& Sadeghi, 2009). Defining the characteristics of an effective EFL teacher is not as simple as it may seem at first sight. It is not surprising to come across several studies (Borg, 2006; Arikan, Tasher \& Sezgi-Sarac-Suzer, 2008; Babai Shishavan \& Sadeghi, Khojastemehr \& Takrimi, 2009; Ozsevik, Arikan, 2010; Chen, 2012, Salahshoor \& Hajizadeh, 2012) focused on teacher 'effectiveness' since it is a matter of quality and not quantity and naturally difficult to provide a definite description for. In the following section more information regarding some of the studies mentioned above will be given. The findings from Salahshour \& Hajizadeh (2012) will be compared with the findings gained from this research regarding teacher's perceptions.

\subsection{Learners' perceptions}

In a recent study Salahshour \& Hajizadeh (2012) conducted a research in Tabriz, in Northwest of Iran, to find out the characteristics of an effective English teacher according to Iranian students and also to identify the item which had the most priority in each category according to the students. Twenty-two (female $=9$ and male $=33$ ) students were questioned using a 58-item questionnaire. To prevent any misunderstandings on the part of the students to give accurate judgments, the researchers spent a good deal of time going through each item in the questionnaire with each of the students. In addition to this, the questionnaire was translated in to the students national language to ensure the clarity of the items. Therefore, the researchers were certain that every student had understood the items in the questionnaire and that there would be no misunderstanding. In addition to this, the questionnaire was translated into the national language to ensure that student read the questionnaire in the language they are most familiar with thus preventing misunderstandings from occurring. The results revealed that the top ten most important features of effective and successful EFL teachers were:

- Having interest in his/her job

- Having a sense of responsibility towards his/her job

- Being enthusiastic and lively

- Being self-confident

- Being punctual

- Encouraging students to use the target language at all times

- Providing explicit grammar correction

- Providing detailed explanation during reading and listening tasks 
- Emphasizing frequent oral quizzes

- Emphasizing all skills specially speaking.

In a study Chen (2012) aimed to investigate the favorable and unfavorable characteristics of the EFL teachers perceived by Thai university students. The characteristics were grouped into personal trait-related and classroom teaching-related characteristics. The personal trait-related characteristics included emotion, kindness, fairness, lenience and responsibility and the classroom teaching-related characteristics were concerned with aspects of lesson delivery, language used in teaching, classroom activity organization and classroom atmosphere creation. An interesting finding, according to Chen, was to discover that some students liked to study with the teachers who spoke English and Thai in the classroom. Some students preferred to study with the foreign teachers who could speak Thai. According to them, if the teacher spoke English and Thai while teaching, they could understand the teaching better and would have higher motivation to learn.

In another study Arikan, Tasher and Sarach-Suzer (2008) aimed to gather data on how Turkish students learning English as a foreign language describe the qualities of an effective English teacher. Their results suggested that students perceive teachers as effective, if they teach both formal and informal English, incorporate games into teaching, and organize group/pair work activities in the classroom. In addition, Turkish students view teachers who use real life situations in the classroom as effective, but do not prefer teachers with high teacher talking time. They also reported that the students in their study found some traits as "ineffective." The students perceived foreign language teachers who are heavily depended on their lesson plans, who do not employ a variety of methods, who disregard the needs of the learners as ineffective teachers. The quantitative results of this research show that an effective teacher is a friendly, young, enthusiastic, creative, and humorous person, regardless of the gender. Also, it was expected that the teacher be a native speaker of Turkish, but fluent in English who likes playing educational games, teaches grammar effectively, uses real life situations to explain language items, and has correct pronunciation.

\subsection{Teachers' perceptions}

A classroom consists of both teachers and students. To enhance the quality of the class, both teachers' and students' opinions on any relevant matter should be taken into consideration. The characteristics of an effective teacher is by no means an exception. Therefore, researchers have not just focused on learners' perceptions of effective EFL instructors; they have also tried to find out teachers' own beliefs and perceptions concerning EFL instructors, too. As KaravasDoukas (1996) stated, "one of the causes of the discrepancy between prescribed theory and classroom practice may be teacher attitude" (p. 187). According to Richardson (1996, 1994), as cited by Sato and Kleinnsasser (1999), "beliefs influence teaching practice more directly than knowledge" (p. 496) and "in order to understand how teachers make sense of teaching and learning, one should focus on teachers' beliefs and practices" (p.496) (cited in Rezaul Karim, 2004, p.28).

Ozsevik (2010) designed a study to investigate the Turkish EFL teachers' understanding of English teaching, predominantly the difficulties and challenges they face in the implementation of CLT practices in the Turkish context. The results showed that Turkish EFL teachers, whilst aware of the achievements, observe many difficulties in implementing CLT in their classrooms. The difficulties stem from four directions, namely, the teacher, the students, the educational system, and CLT itself. The results of this study suggested that despite showing keen interest in change and being eager to identify with CLT, Turkish teachers were not quite optimistic about the complete adoption of CLT, and thus felt that only by overcoming the difficulties from those four sources, and by establishing more favorable conditions for the implementation of CLT could teachers truly benefit from CLT in their English classrooms.

Khojastehmehr \& Takrimi (2009) in a study tried to identify the characteristics of effective teachers based on perceptions of the English teachers in Khuzestan, in south of Iran in which 215 male and female secondary school English teachers filled a 50-item researcher-constructed questionnaire. Their study indicated that to those teachers, instructional strategies were viewed as more critical for teacher effectiveness than communication (social) skills, personal characteristics and knowledge.

\subsection{Comparative studies}

Investigating opinions on the characteristics of the effective teachers seems to yield a better result if both teachers and learners' opinions are compared to each other in case there should be any mismatches between what are considered to be of priority to each side. Some researchers, therefore, tried to make a comparison between teachers' and learners' beliefs. To the best knowledge of the researchers of this article, there has been only one study with a comparative nature on this matter in Iran.

In an investigation of the characteristics of an effective English language teacher, Babai Shishavan \& Sadeghi (2009) compared the perceptions of Iranian English language teachers and learners. They used a tailor-made questionnaire. Their findings showed teachers and learners of English hold different views towards some characteristics of an effective English language teacher. On the whole, in their study, the teachers perceived features like high knowledge of pedagogy and the use of particular techniques and methods such as preparing the lesson well, using lesson plans, unbiased assessment of what students have learned, integrating group activities to class and assigning homework to be possessed by effective English language teachers. However, the learners assigned more weight to characteristics relating to a teachers' personality and the way he behaves with his students. Moreover, whereas the teachers only concentrated on the positive characteristics of an effective teacher, such as being patient, being flexible and caring about students' needs, being optimist and having positive attitude toward the students, and being smart and creative, the students- 
considering these positive qualities important - focused also on the characteristics that may affect a teacher's efficacy adversely like speaking a lot about his/her personal experiences. Their findings also showed that students, on the contrary, agreed more than teachers that teaching English in Persian (first language of the learners) was one of the prominent characteristics of an Effective English Language Teachers (EELT). All those observations indicated that teachers look at an effective teacher from the professional point of view and their responses are more informed reflecting their knowledge and expertise on theories and methodology of language teaching. The students' perspectives also seemed very realistic and the fact that they considered both strong and weak points of their teachers can help teachers to reflect on their own behaviors in the classroom and try to overcome the possible problems resulting in deficiency.

Having reviewed the findings of the previous studies conducted on characteristics of effective English teachers revealed that there have been only two studies with a comparative nature on this matter in Iran which were mentioned above. As it was mentioned before, 'effectiveness' has a qualitative nature. Therefore conducting the previously mentioned studies did not put an end to further research on this matter and the gap has not been filled yet. This fact motivated us to do this study with a comparative nature on the characteristics of effective EFL teachers in the Northwest of Iran. Salahshour and Hajizadeh (2012) had investigated the perceptions of learners on characteristics of effective EFL teachers in a previous study. The details of that study have been mentioned above. To be able to have a comparison, the researchers decided to conduct this research to study the perceptions of teachers and compare the results with that of the 'students'. We tried to find whether or not there are mismatches between what teachers and learners define as characteristics of an effective EFL instructor which may result in clashes between what is expected and what is experienced by both learners and instructors in EFL classes in Iran. Considering the fact that Iran is a developing country, the number of the private institutes has been increasing significantly over the recent years in response to the high demand for learning a foreign language to be able to catch up with the outer developed world. This fact acknowledges the need to conduct as many studies as possible to investigate and improve the context of the classes as the only true opportunity to learn a foreign language systematically.

\section{Research questions}

By carrying out this research we focused on these questions:

1. What are the characteristics of an effective English language instructor according to instructors themselves?

2. What are the prominent items among the characteristics of an effective English language instructor?

3. Are there any major discrepancies between learners and instructors' beliefs and perceptions concerning the effective English language instructors or not?

We also theorized that the probable mismatches between learners and instructors' perceptions may be the reason why English classes are not in line with learners' expectations in Iran.

\section{Participants}

The participants in this study were 18 (female= 12 and male=6) EFL teachers with 21-34 years of age and half a year to twelve years of experience of teaching in different private language institutes in Tabriz, Northwest of Iran. It should also be mentioned that all the he participants in this study were selected randomly.

\section{Instrument}

To be able to make a meaningful comparison of instructors and learners' perceptions, the researchers used the same questionnaire developed by Salahshour \& Hajizadeh (2012) to investigate learners' perceptions concerning an effective EFL instructor in a previous research. The items were categorized into eight sections which were titled as follows: Personal Qualities, Command in English, Teaching Methodology, Evaluation Method, Amount of Teacher's Emphasis on Different Skills, Mastery over teaching, Teacher-Student Relationship and Class Management/Institutes Program. Each item was rated on a four-point scale as not important at all, somehow important, important, and very important. The questionnaire also included a free writing section at last to make it possible for the participants to add any other comment regarding the subject of the study. All the items were later translated into the participants' national language, i.e. Persian, to avoid possible misunderstandings. For more details about the questionnaire refer to Salahshour \& Hajizadeh (2012).

\section{Procedure}

The questionnaire was administered to the EFL teachers either in person or through e-mail. The teachers were asked to specify the degree of the importance of each item as Not Important At All, Somehow Important, Important or Very important. They were also asked to number the items in each category based on the order that seemed the most appropriate according to them. Having been completed by the teachers, the questionnaires were analyzed based on the percentage of each item calculated. The same procedure and instrument had been used in a previous study by Salahshour \& Hajizadeh (2012). They conducted a research in Tabriz, in Northwest of Iran, to find out the characteristics of an effective English teacher according to Iranian students and also to identify the item which had the most priority in each category according to the students. Twenty-two (female $=9$ and male $=33$ ) students had participated in their study. 
The result for each table in the present study was later compared to that of the learners', the list of which has been provided in appendix 1, to identify whether there were consistencies or inconsistencies between teachers and learners' perceptions regarding each category.

\section{Results}

Table 1 was designed to elicit the teachers' perception about the effective teacher's personal qualities. What is evident in this table is that more than half of the participants $(55 \%)$ believed that teacher's gender is not important at all. Teacher's age was also perceived to be of no importance by $16 \%$ of the participants. The most frequently selected quality in this table was being self-confident which was marked as very important by $88 \%$ of the teachers. Having interest in his/her job and feeling responsibility for teaching was also identified as very important by a majority of the participants (83\%). Both items, i.e. being self-confident and having interest in his/her job and feeling responsibility, were each also equally marked as the first priority by half of the participants (50\%) in this category. Being enthusiastic and lively and being creative and spontaneous are among other factors which more than half of the participants unanimously marked as very important.

\section{Similarities between Teachers and Learners' Beliefs}

Comparing this table with that of the learners' perceptions by considering what the majority of participants in either study believed about each item revealed consistencies concerning most items in this table. Both teachers and learners thought similarly about the degree of importance of items 1, 2, 5, 6, 8 and 10 .

\section{Differences between Teachers and Learners' Beliefs}

Teachers' self-confidence seemed to be of more importance to teachers themselves since $88 \%$ of the teachers identified this item as very important and half of them also marked it as the first priority while only $54 \%$ of the students chose this item as very important and the number of students who marked it as first priority was not large (19\%). It was also interesting that half of the students $(50 \%)$ believed that the teacher's good appearance was just somehow important and about 10 per cent $(9.52 \%)$ even considered it as not important at all while $40 \%$ of the teachers considered it as important.

\begin{tabular}{|c|c|c|c|c|c|c|}
\hline $\begin{array}{c}\text { Item } \\
\text { Number }\end{array}$ & Item & $\begin{array}{l}\text { Marked as } \\
\text { First } \\
\text { Priority in } \\
\text { this } \\
\text { Category }\end{array}$ & $\begin{array}{c}\text { Not important } \\
\text { at all }\end{array}$ & $\begin{array}{l}\text { Somehow } \\
\text { Important }\end{array}$ & Important & $\begin{array}{c}\text { Very } \\
\text { Important }\end{array}$ \\
\hline 1 & Teacher's gender & 0 & 55 & 11 & 33 & 0 \\
\hline 2 & Teacher's age & 0 & 16 & 44 & 16 & 22 \\
\hline 3 & Good Appearance & 5 & 0 & 27 & 44 & 27 \\
\hline 4 & Being self-confident & 50 & 0 & 0 & 11 & 88 \\
\hline 5 & $\begin{array}{l}\text { Being enthusiastic } \\
\text { and lively }\end{array}$ & 11 & 0 & 0 & 27 & 72 \\
\hline 6 & $\begin{array}{l}\text { Being creative and } \\
\text { spontaneous }\end{array}$ & 5 & 0 & 5 & 27 & 66 \\
\hline 7 & $\begin{array}{l}\text { Having a loud and } \\
\text { clear voice }\end{array}$ & 0 & 0 & 16 & 44 & 38 \\
\hline 8 & $\begin{array}{l}\text { Being punctual ( in } \\
\text { terms of starting the } \\
\text { class and returning } \\
\text { students' papers) }\end{array}$ & 0 & 0 & 11 & 44 & 44 \\
\hline 9 & $\begin{array}{l}\text { Having patience with } \\
\text { students }\end{array}$ & 0 & 0 & 0 & 38 & 61 \\
\hline 10 & $\begin{array}{l}\text { Having interest in } \\
\text { his/her job and } \\
\text { feeling responsibility } \\
\text { for teaching }\end{array}$ & 50 & 0 & 5 & 11 & 83 \\
\hline
\end{tabular}

Table 2 concerns the teacher's command in English. It is obvious that all factors have a degree of importance because no one marked any factor as not important at all. Apart from $11 \%$ of the participants who chose accuracy of teacher's intonation as somehow important, all the other participants marked all factors as either important or very important. The majority of the participants (83\%) considered accuracy of teacher's structure as very important and $50 \%$ also marked it as the first priority in this category. Seventy seven per cent of the participants believed that both accuracy of teacher's pronunciation and his/her fluency in the foreign language are very important. Although both factors are considered as very important, a look at the second column indicates that being fluent seems to be of more importance to a teacher than having the accurate pronunciation because $33 \%$ of the participants marked it as the prior factor while only $22 \%$ considered the accurate pronunciation as their first choice. 


\section{Similarities between Teachers and Learners' Beliefs}

When teachers and students' ideas were compared, there seemed to be agreement between what they thought about a teacher's command in English concerning almost all items except for the degree of importance they allocated to teacher's vocabulary and structure.

\section{Differences between Teachers and Learners' Beliefs}

A vast majority of students (83\%) believed that an effective teacher's accuracy of vocabulary is very important. However, this item was considered as very important only by $55 \%$ of the teachers. Teachers on the other hand considered the structure to be much more important than the vocabulary.

Table 2. Command in English (\%)

\begin{tabular}{|c|c|c|c|c|c|c|}
\hline $\begin{array}{l}\text { Item } \\
\text { Number }\end{array}$ & Item & $\begin{array}{l}\text { Marked as First } \\
\text { Priority in this } \\
\text { Category }\end{array}$ & $\begin{array}{l}\text { Not } \\
\text { important } \\
\text { at all }\end{array}$ & $\begin{array}{l}\text { Somehow } \\
\text { Important }\end{array}$ & Important & Very Important \\
\hline 1 & $\begin{array}{l}\text { Accuracy of } \\
\text { teacher } \\
\text { vocabulary }\end{array}$ & 22 & 0 & 0 & 44 & 55 \\
\hline 2 & $\begin{array}{l}\text { Accuracy of } \\
\text { teacher structure }\end{array}$ & 50 & 0 & 0 & 16 & 83 \\
\hline 3 & $\begin{array}{l}\text { Accuracy of } \\
\text { pronunciation }\end{array}$ & 22 & 0 & 0 & 22 & 77 \\
\hline 4 & $\begin{array}{l}\text { Accuracy of } \\
\text { intonation }\end{array}$ & 5 & 0 & 11 & 50 & 38 \\
\hline 5 & $\begin{array}{l}\text { Fluency in the } \\
\text { foreign language }\end{array}$ & 33 & 0 & 0 & 22 & 77 \\
\hline
\end{tabular}

Table 3 focuses on teaching methodology. Among the 12 factors in this table, using the students' native language when necessary was considered as not important at all by $22 \%$ of the participants and $44 \%$ marked it as somehow important. On the other hand encouraging students to use the English language ALL THE TIME in class was conceived as very important by a large number of participants (66\%) and $22 \%$ marked it as their first priority in this category. More than half of the participants (55\%) also believed that using appropriate teaching techniques and use of pair work are very important for an effective English teacher. Looking at factors that are considered as important revealed that using pantomime, pictures and acting to clarify points was the most frequently marked item in this column (61\%) which implies the fact that translating is not considered as an acceptable means of clarifying by an effective teacher as long as other ways are available.

\section{Similarities between Teachers and Learners' Beliefs}

Regarding teaching methodology, teachers and students were quite unanimous in what they believed about items $1,3,4$, $5,6,8,11$ and 12 .

\section{Differences between Teachers and Learners' Beliefs}

There seemed, however, to be some discrepancies between two groups' opinions, too. More than half of teachers (61\%) believed that using pantomime, pictures and acting to clarify points in class was important for an effective teacher. On the other hand students didn't seem to be that much interested in getting the points through pantomime, pictures and acting. Twenty-three per cent of the students even said that it was not important at all which clearly showed that students have an unconscious tendency to receive points through more direct ways. Items 9 and 10 also should to be taken into consideration. All teachers allocated a degree of importance to use of pair work and use of group work in class. More than half of them (55\%) marked pair work as very important and $44 \%$ reported use of group work to be important. Students, on the contrary, didn't show interest in these items. Forty per cent of them believed that pair work and group work were only somehow important and $11 \%$ and $14 \%$ of the students considered these two items to be not important at all. It is evident that Iranian EFL students are strongly affected by the traditional ways of teaching at schools and universities. They have got used to work competitively and individually in classes and consequently do not show interest toward working collaboratively in class to learn. This refers to one of difficulties EFL instructors may encounter while trying to put the principals of CLT into practice in a context with a traditional educational system. 


\begin{tabular}{|c|c|c|c|c|c|c|}
\hline $\begin{array}{l}\text { Item } \\
\text { Number }\end{array}$ & Item & $\begin{array}{l}\text { Marked as First } \\
\text { Priority in this } \\
\text { Category }\end{array}$ & $\begin{array}{l}\text { Not } \\
\text { important at } \\
\text { all }\end{array}$ & $\begin{array}{l}\text { Somehow } \\
\text { Important }\end{array}$ & Important & $\begin{array}{l}\text { Very } \\
\text { Important }\end{array}$ \\
\hline 1 & $\begin{array}{l}\text { Using appropriate } \\
\text { teaching techniques }\end{array}$ & 55 & 0 & 5 & 38 & 55 \\
\hline 2 & $\begin{array}{l}\text { Using pantomime, } \\
\text { pictures and acting } \\
\text { to clarify points }\end{array}$ & 11 & 0 & 16 & 61 & 22 \\
\hline 3 & $\begin{array}{l}\text { Providing detailed } \\
\text { explanations while } \\
\text { reading/listening } \\
\text { (e.g., checking ALL } \\
\text { the new } \\
\text { vocabularies) }\end{array}$ & 5 & 5 & 44 & 27 & 22 \\
\hline 4 & $\begin{array}{l}\text { Using the students' } \\
\text { native language } \\
\text { when necessary }\end{array}$ & 0 & 22 & 44 & 33 & 0 \\
\hline 5 & $\begin{array}{l}\text { Going beyond } \\
\text { textbook when } \\
\text { teaching }\end{array}$ & 0 & 16 & 44 & 33 & 5 \\
\hline 6 & $\begin{array}{l}\text { Providing cultural } \\
\text { information about } \\
\text { the target language's } \\
\text { culture }\end{array}$ & 22 & 0 & 27 & 44 & 27 \\
\hline 7 & $\begin{array}{l}\text { Providing explicit } \\
\text { error correction }\end{array}$ & 0 & 11 & 55 & 16 & 16 \\
\hline 8 & $\begin{array}{l}\text { Giving regular } \\
\text { homework tasks }\end{array}$ & 0 & 0 & 27 & 44 & 27 \\
\hline 9 & Use of Pair work & 5 & 0 & 27 & 16 & 55 \\
\hline 10 & Use of group work & 5 & 0 & 16 & 44 & 38 \\
\hline 11 & $\begin{array}{l}\text { Using suitable } \\
\text { amount of teacher } \\
\text { talk }\end{array}$ & 5 & 0 & 5 & 55 & 38 \\
\hline 12 & $\begin{array}{l}\text { Encouraging } \\
\text { students to use the } \\
\text { English language } \\
\text { ALL THE TIME in } \\
\text { class }\end{array}$ & 22 & 0 & 5 & 27 & 66 \\
\hline
\end{tabular}

The most obvious fact regarding table 4 which concerns evaluation method is that the majority of participants (83\%) who are teachers themselves would rather ask oral questions at the beginning of each session. Comparing the number of participants who marked either item as very important once more shows a tendency toward oral questions, since only $22 \%$ of the participants marked quizzes as very important while more than half of them (55\%) believed that oral questions are very important.

No difference was identified between teachers and students' perceptions of an effective teacher's evaluation method.

Table 4. Evaluation Method (\%)

\begin{tabular}{lllllll}
\hline Item & Item & $\begin{array}{l}\text { Marked } \\
\text { as First } \\
\text { Priority } \\
\text { in this } \\
\text { Category }\end{array}$ & $\begin{array}{l}\text { Not } \\
\text { important at } \\
\text { all }\end{array}$ & $\begin{array}{l}\text { Somehow } \\
\text { Important }\end{array}$ & Important & $\begin{array}{l}\text { Very } \\
\text { Important }\end{array}$ \\
\hline 1 & 27 & 5 & 38 & 33 & 22 \\
2 & $\begin{array}{l}\text { Giving quizzes } \\
\text { frequently } \\
\text { Asking oral questions at } \\
\text { the beginning of each } \\
\text { session }\end{array}$ & 83 & 0 & 5 & 38 & 55 \\
\hline
\end{tabular}

Table 5 represents the amount of teacher's emphasis on different skills in class. As was expected, no teacher chose any item as not important at all, because emphasizing each item has its own merits. Among the responses, two items exhibited a strong consensus. The first was emphasizing speaking which was selected most frequently (77\%) as very 
important. A large number of teachers (72\%) also identified emphasizing listening as very important. An interesting fact concerning this table is that emphasizing grammar and emphasizing vocabulary both have exactly the same degree of importance in each column to teachers. In the case of the item marked as the first priority in this category, emphasizing speaking once more exhibited the strongest consensus as $66 \%$ of the participants marked it as the first priority.

\section{Similarities between Teachers and Learners' Beliefs}

Comparing teachers and students' opinions did not show a major difference between two groups concerning the amount of teacher's emphasis on different skills. Therefore, they were in complete agreement on the items in this table.

Table 5. Amount of Teacher's Emphasis on Different Skills (\%)

\begin{tabular}{lllllll}
$\begin{array}{l}\text { Item } \\
\text { Number }\end{array}$ & Item & $\begin{array}{c}\text { Marked as } \\
\text { First } \\
\text { Priority in } \\
\text { this } \\
\text { Category }\end{array}$ & $\begin{array}{l}\text { Not important } \\
\text { at all }\end{array}$ & $\begin{array}{l}\text { Somehow } \\
\text { Important }\end{array}$ & Important & $\begin{array}{l}\text { Very } \\
\text { Important }\end{array}$ \\
\hline 1 & Emphasizing grammar & 16 & 0 & 22 & 55 & 22 \\
2 & Emphasizing speaking & 66 & 0 & 0 & 22 & 77 \\
3 & Emphasizing vocabulary & 5 & 0 & 22 & 55 & 22 \\
4 & Emphasizing listening & 27 & 0 & 0 & 27 & 72 \\
\hline
\end{tabular}

Table 6 was intended to capture the participants' perception about the teacher's mastery over teaching. The only item selected as not important at all was teacher's knowledge of students' specialist courses which was marked by $27 \%$ of the participants. The item selected most frequently (83\%) concerning an effective teacher's mastery over teaching was capability to communicate ideas, knowledge, and intended teaching items. Consistency in identifying this item as the most important one in this table was also evident from the fact that $66 \%$ of the teachers marked it as the first priority in this category. The second item marked as very important in this category was knowledge of the subject matter which was selected by more than half of the participants (55\%). It implies the fact that merely being able to speak a foreign language doesn't make one an effective teacher.

\section{Similarities between Teachers and Learners' Beliefs}

Taking both teachers and students opinions into consideration, the researchers concluded that both groups had almost the same idea about items 2, 5, 7 and 8 .

\section{Differences between Teachers and Learners' Beliefs}

The teacher's capability to communicate ideas, knowledge, intended teaching items was not as important according to students as it was to teachers. A large number of teachers $(83 \%)$ believed that this factor was very important to an effective teacher and $66 \%$ stated that it was the first priority in this category. Students did not seem to think the same way since only $45 \%$, i.e. less than half, of them marked it as very important. Half of the students (50\%) thought that preparation and lesson planning was very important to a teacher and 38\% of the teachers marked it as very important and 55\% as important. Therefore, from the students' point of view the degree of the importance of this item for a teacher was conceived to be higher compared to that of teachers'. It was also revealed that teachers and students were not completely consistent in what they thought about a teacher's capability to answer students' questions. More than half of the students were in agreement to choose this item as very important, however only $38 \%$ of the teachers believed this way.

Table 6. Mastery over Teaching (\%)

\begin{tabular}{|c|c|c|c|c|c|c|}
\hline $\begin{array}{l}\text { Item } \\
\text { Number }\end{array}$ & Item & $\begin{array}{l}\text { Marked } \\
\text { as First } \\
\text { Priority } \\
\text { in this } \\
\text { Category }\end{array}$ & $\begin{array}{l}\text { Not } \\
\text { important at } \\
\text { all }\end{array}$ & $\begin{array}{l}\text { Somehow } \\
\text { Important }\end{array}$ & Important & $\begin{array}{l}\text { Very } \\
\text { Important }\end{array}$ \\
\hline 1 & $\begin{array}{l}\text { Capability to } \\
\text { communicate ideas, } \\
\text { knowledge, intended } \\
\text { teaching items }\end{array}$ & 66 & 0 & 0 & 16 & 83 \\
\hline 2 & $\begin{array}{l}\text { Knowledge of the subject } \\
\text { matter }\end{array}$ & 33 & 0 & 5 & 38 & 55 \\
\hline 3 & $\begin{array}{l}\text { Preparation and lesson } \\
\text { planning }\end{array}$ & 5 & 0 & 5 & 55 & 38 \\
\hline 4 & $\begin{array}{l}\text { Capability to answer } \\
\text { students questions }\end{array}$ & 0 & 0 & 11 & 50 & 38 \\
\hline 5 & Use of efficient and & 5 & 0 & 22 & 44 & 33 \\
\hline
\end{tabular}


adequate methods of

elicitation while teaching

$6 \quad$ Ability to guide students

$5 \quad 0$

$0 \quad 22$

55

to independent learning

$7 \quad$ knowledge of students'

0

27

44

27

0

specialist courses

8 Ability to identify the

0

0

16

50

33

students learning styles

To determine the participants' perception of teacher-student relation a list of 12 items was presented as table 7. An effective teacher was strongly expected to be able to create motivation in students; it was evident from the fact that $77 \%$ of the participants unanimously marked it as very important. It was not, however, the first priority to all these teachers because only $27 \%$ believed it to be the first priority. Although having respect for students and helping to create selfconfidence in students both were the second item with the highest percentage (72\%) in this category, it was having respect for students which was conceived as the first Priority in this table from the viewpoint of $55 \%$ of the teachers. The only factors perceived to be not important at all concerning the teacher-student relation were having contact with the students' parents, being available outside of class and having knowledge of students' mother tongue which were marked by $33 \%, 16 \%$ and $11 \%$ of the teachers respectively.

\section{Similarities between Teachers and Learners' Beliefs}

Studying both teachers and students' choices concerning teacher-student relation made it clear that the degree of importance of items 1, 2, 3, 4, 5, 7, 9, 10 and 11 were almost the same to both teacher and students.

\section{Differences between Teachers and Learners' Beliefs}

Regarding attracting and maintaining students' attention showed that $57 \%$ of the students thought it to be important for an effective instructor. That the degree of this item was higher according to teachers was evident from the fact that $66 \%$ of teachers marked this item as very important to an effective instructor. It was also noted that a teacher's knowledge of students' mother tongue was considered as very important by $14 \%$ of the students while no teacher believed this item to be very important. Being available outside of class did not prove to be considered as a remarkable merit for a teacher according to students, because $33 \%$ of them thought that it was not important at all and only $4 \%$ mentioned that it was very important. However, no teacher marked this factor as not important at all and half of them believed that it was important and it even seemed very important to $27 \%$ of teachers.

\begin{tabular}{|c|c|c|c|c|c|c|}
\hline $\begin{array}{l}\text { Item } \\
\text { Number }\end{array}$ & Item & $\begin{array}{l}\text { Marked as } \\
\text { First } \\
\text { Priority in } \\
\text { this } \\
\text { Category } \\
\end{array}$ & $\begin{array}{l}\text { Not important } \\
\text { at all }\end{array}$ & $\begin{array}{l}\text { Somehow } \\
\text { Important }\end{array}$ & Important & $\begin{array}{l}\text { Very } \\
\text { Important }\end{array}$ \\
\hline 1 & Having respect for students & 55 & 0 & 0 & 27 & 72 \\
\hline 2 & $\begin{array}{l}\text { Being kind and friendly } \\
\text { with students }\end{array}$ & 11 & 0 & 16 & 33 & 50 \\
\hline 3 & Encouraging participation & 16 & 0 & 11 & 22 & 66 \\
\hline 4 & Creating motivation & 27 & 0 & 0 & 22 & 77 \\
\hline 5 & $\begin{array}{l}\text { Helping to create self- } \\
\text { confidence in students }\end{array}$ & 27 & 0 & 0 & 27 & 72 \\
\hline 6 & $\begin{array}{l}\text { Attracting and maintaining } \\
\text { Students' attention }\end{array}$ & 11 & 0 & 5 & 27 & 66 \\
\hline 7 & Individual help to students & 11 & 0 & 27 & 38 & 33 \\
\hline 8 & $\begin{array}{l}\text { Knowledge of students' } \\
\text { mother tongue }\end{array}$ & 0 & 11 & 55 & 33 & 0 \\
\hline 9 & $\begin{array}{l}\text { Providing appropriate } \\
\text { feedback to students }\end{array}$ & 11 & 0 & 5 & 72 & 22 \\
\hline 10 & $\begin{array}{l}\text { Having contact with the } \\
\text { students' parents }\end{array}$ & 0 & 33 & 55 & 11 & 0 \\
\hline 11 & $\begin{array}{l}\text { Asking for students' } \\
\text { feedback (about the class } \\
\text { and teaching method) }\end{array}$ & 5 & 0 & 22 & 50 & 27 \\
\hline 12 & $\begin{array}{l}\text { Being available outside of } \\
\text { class }\end{array}$ & 0 & 16 & 50 & 27 & 5 \\
\hline
\end{tabular}


Table 8 was the last table in the questionnaire which takes class management and institutes programmes into consideration. Eleven per cent of the participants believed that using white board efficiently, i.e., using colorful markers and writing well was not important at all while $50 \%$ conceived it to be important for a teacher. No other item was marked as being not important at all for an effective teacher. In the case of item 2, that is using class time wisely, a majority of the teachers (83\%) marked it as very important which proved it to be the most frequently selected item in this table. Seventy seven per cent of the participants identified maintaining order in class/class control as a very important item concerning class management. Being selected by $33 \%$ of the teachers also confirmed this item to be the first priority in this category. Movement around the class, which provides the opportunity to monitor and attract each individual student's attention, was another item which was perceived by more than half of the participants (66\%) to be very important in this category.

\section{Similarities between Teachers and Learners' Beliefs}

Using white board efficiently, using the class time wisely and following the material specified by the institute were three items which were identified to have the same degree of importance to both teachers and students.

\section{Differences between Teachers and Learners' Beliefs}

Although maintaining order in class/class control was considered to be very important to both groups, there was a noticeable difference in the number of people who marked it as very important in both groups. Only $45 \%$ of the students thought it to be very important while a large number of teachers $(77 \%)$ chose this item as very important. There was also a considerable difference in number of people who considered teacher's movement around the class as very important. Sixty-six per cent of teachers believed that this item was very important for a teacher, but only $30 \%$ of the students had the same idea and $35 \%$ stated that it was just important.

\begin{tabular}{|c|c|c|c|c|c|c|}
\hline $\begin{array}{l}\text { Item } \\
\text { Number }\end{array}$ & Item & $\begin{array}{l}\text { Marked as } \\
\text { First } \\
\text { Priority in } \\
\text { this } \\
\text { Category } \\
\end{array}$ & $\begin{array}{l}\text { Not important } \\
\text { at all }\end{array}$ & $\begin{array}{l}\text { Somehow } \\
\text { Important }\end{array}$ & Important & $\begin{array}{l}\text { Very } \\
\text { Important }\end{array}$ \\
\hline 1 & $\begin{array}{l}\text { Use of White board } \\
\text { efficiently ( using colourful } \\
\text { markers and writing well) }\end{array}$ & 16 & 11 & 11 & 50 & 27 \\
\hline 2 & Using class time wisely & 27 & 0 & 11 & 5 & 83 \\
\hline 3 & $\begin{array}{l}\text { Maintaining order in } \\
\text { Class/Class control }\end{array}$ & 33 & 0 & 5 & 16 & 77 \\
\hline 4 & $\begin{array}{l}\text { Following the material } \\
\text { specified and guidelines } \\
\text { provided by the institute }\end{array}$ & 11 & 0 & 16 & 61 & 22 \\
\hline 5 & Movement around the class & 16 & 0 & 16 & 16 & 66 \\
\hline
\end{tabular}

To have a better understanding of the items which were marked as first priority in each category by teachers and students the researchers devised another table. Furthermore, to be able to compare teachers and learners' beliefs in detail regarding this matter the researchers also decided to illustrate both first and second items marked as first priority in each category. Table 9 consists of three columns. The first column illustrates the number of the tables in the questionnaire; the second column contains first two items marked as first priority in each category by students and the third column provides first two items marked as first priority in each category by teachers. The first and second item in each part has been distinguished by using 'a' to refer to the first priority and ' $b$ ' to the second one. The number of people who chose each item is also mentioned in percentage in front of each one.

\section{Similarities between Teachers and Learners' Beliefs}

Given the total number of items in the questionnaire, i.e. 58, the result was surprising. As can be seen, four tables out of eight demonstrate a complete consistency between teachers and learners' perceptions concerning the first priority in each category. It is very interesting that in tables 1,3,4 and 5 not only are the first items identified by both teachers and learners identical, but the second ones also are proved to be the same. Therefore according to half of the tables, an effective teacher's interest in his/her job and feeling responsibility for teaching, use of appropriate teaching techniques, asking oral questions at the beginning of each session and emphasizing speaking are believed to be of priority for both teachers and learners

Another fascinating result is that in the rest of tables except for table 6, the relationship between the two items in the second and third columns has the same pattern. In tables 2, 7 and 8 the first item marked as first priority by students has been specified as the second item marked as the first priority in that category by teachers. For example, table 8 shows that using class time wisely is the most frequently marked item as the first priority in this category while it has been specified as the second item which was frequently marked by teachers as the first priority. Taking a look at table 2 
shows that students believe that it is accuracy of teacher vocabulary which is the most important factor for a teacher while teachers themselves think that accuracy of structure has first priority for an EFL teacher.

\section{Differences between Teachers and Learners' Beliefs}

The only difference between teachers and learners' perceptions concerning the first priority in each category is in table 6. Capability to communicate ideas, knowledge, and intended teaching items was the item marked by teachers as the first priority in this table. Students did not have the same idea. They believed that it was knowledge of the subject matter which was the first priority in this table. Interestingly this item was the second item which was marked as the first priority by teachers themselves.

Table 9. Items marked as first priority by students and teachers

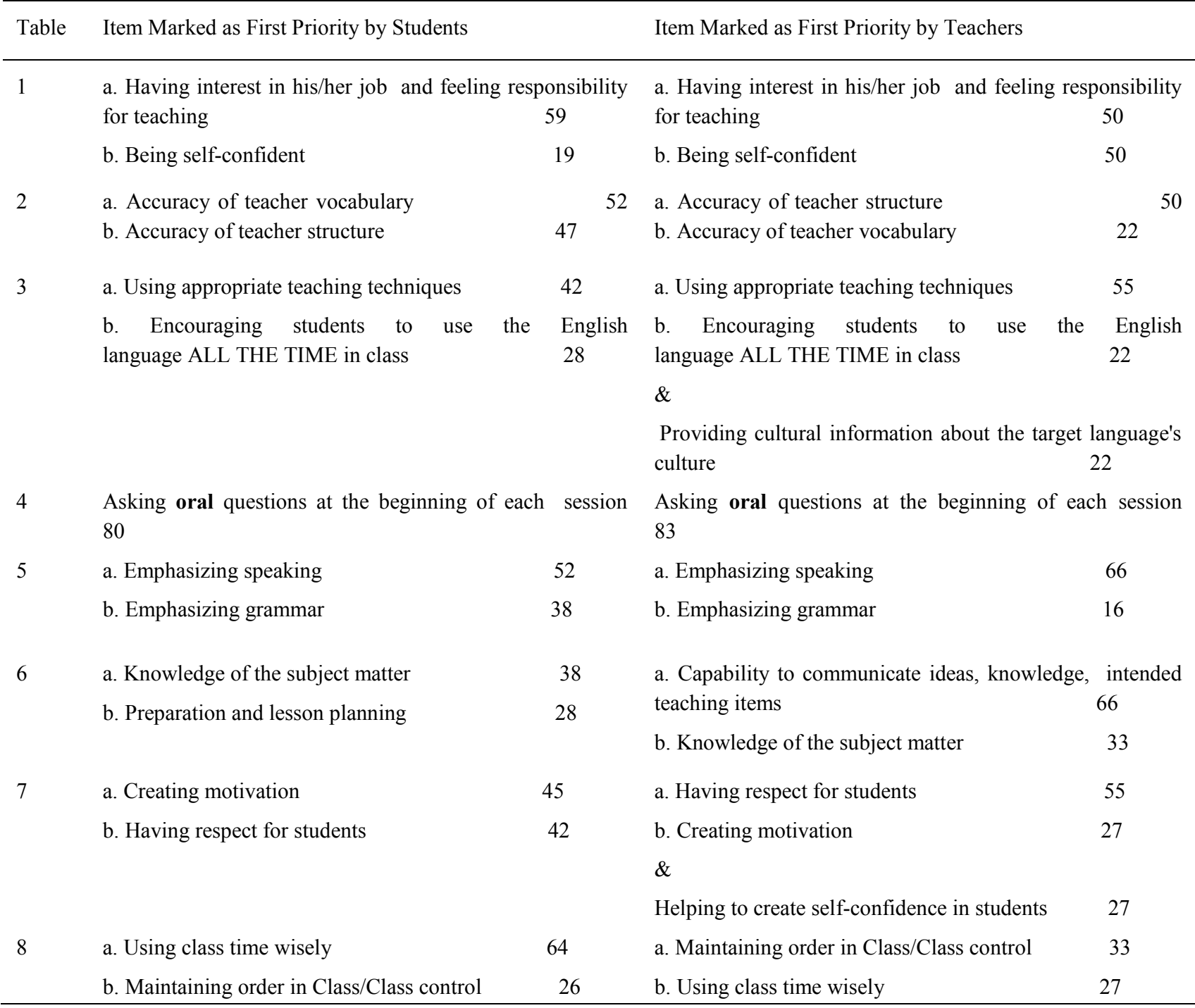

\section{Conclusions}

This research attempted to find out EFL teachers' perceptions concerning the characteristics of an effective English language EFL instructor. It also tried to identify the prominent item in each category according to teachers themselves. In addition, the teachers' perception was compared to that of learners' to see if there were discrepancies between learners and instructors' beliefs and perceptions concerning the effective English language instructors or not. The researchers also theorized that the probable mismatches between learners and instructors' perceptions may be the reason why English classes are not in line with learners' expectations in Iran. The results indicated that according to teachers, some of the most important features of an effective and successful EFL teacher are:

- Being self-confident (88\%)

- Accuracy of teacher structure (83\%)

- Capability to communicate ideas, knowledge, intended teaching items (83\%)

- Having interest in his/her job and feeling responsibility for teaching (83\%)

- Using class time wisely (83\%)

- Creating motivation (77\%) 
- Emphasizing speaking (77\%)

- Maintaining order in Class/Class control (77\%)

- Being enthusiastic and lively (72\%)

- Having respect for students (72\%)

- Helping to create self-confidence in students $(72 \%)$

- Encouraging students to use the English language ALL THE TIME in class (66\%)

- Asking oral questions at the beginning of each session (55\%)

- Knowledge of the subject matter (55\%)

- Using appropriate teaching techniques (55\%)

Regarding the second research question, according to teachers the prominent item in each category concerning the characteristics of an effective English language instructor are:

- Personal Qualities: Having interest in his/her job and feeling responsibility for teaching

- Command in English: Accuracy of teacher structure

- Teaching Methodology: Using appropriate teaching techniques

- Evaluation Method: Asking oral questions at the beginning of each session

- Amount of Teacher's Emphasis on Different Skills: Emphasizing speaking

- Mastery over Teaching: Capability to communicate ideas, knowledge, intended teaching items

- Teacher-Student Relation: Having respect for students

- Class Management: Maintaining order in class/class control

Comparing the teachers and learners' perceptions meticulously provided evidence that the students' perceptions and teachers' perceptions do not differ in major ways. There were of course some mismatches between the two groups which are now revealed and can be taken into consideration. Therefore, the findings of this study in terms of (the amount of) similarities and differences between the learners and the teachers' perceptions ran against the findings of Babai Shishavan \& Sadeghi (2009), the only available study with a comparative nature on this matter. Having studied their conclusions, the present study's researchers deduced that they had recognized more mismatches than matches between teachers' and learners' perceptions. However in the present study much more similarities than differences were identified between two groups' perceptions.

Institutions' attempts to educate effective EFL teachers without surveying both learners and teachers' definition of an effective teacher would be vain. Conducting such research to define an effective EFL instructor' characteristics would pave the way for both language institutions and instructors themselves to make the distance between learner's expectations and experiences in EFL classes as shorter as possible. Emphasizing learner's expectations arises from the fact that CLT is a learner centered approach. If the teacher should manage the class, he or she should not fail to take the learners expectations into consideration.

It should be acknowledged that the sample of this study was small and it was restricted to one city in Iran. Carrying out other research with a larger sample and in different contexts can give us a clearer picture on the characteristics of an effective EFL instructor.

\section{References}

Arikan, A. (2010). Effective English language teacher from the perspective of prospective and in-service teachers in Turkey. Electronic Journal of Social Sciences, 9(31), 209-223.

Arikan, A., Tasher, D., \& Sarach Suzer, H. . (2008). The effective English language teacher from the perspective of Turkish preparatory school students. Education and Science, 33(150), 42-51.

Babai Shishavan, H., \& Sadeghi, K. (2009). Characteristics of an effective English language teacher as perceived by Iranian teachers and learners of English. English Language Teaching, 2(4), 130-143.

Borg, S. (2006). The distinctive characteristics of foreign language teachers. Language Teaching Research, 10(1), 3-31. Chen, J. (2012). Favourable and unfavourable characteristics of EFL teachers perceived by university students in Thailand. International Journal of English Linguistics, 2(1), 213-219.

Khojastemehr, R., \& Takrimi, A. (2009). Characteristics of effective teachers: perceptions of the English teachers. Journal of Education and Psychology, 3(2), 53-66.

Ozsevik, Z. (2010). The use of communicative language teaching (CLT): Turkish EFL teachers' perceived difficulties in implementing CLT in Turkey (Master's). University of Illinois at Urbana-Champaign. Retrieved from https://www.ideals.illinois.edu/handle/2142/16211 
ResaulKarim, M. (2004). Teachers' perceptions, attitudes and expectations about Communicative Language Teaching (CLT) in post-secondary education in Bangladesh (Master's). University of Victoria, Canada. Retrieved from http://webcache.googleusercontent.com/search?q=cache:A7gmudrc8GIJ:dspace.library.uvic.ca:8080/bitstream/handle/1 828/560/karim_2004.pdf\%3Fsequence\%3D1+\&cd=1\&hl=en\&ct=clnk\&gl=nz

Salahshour, N., \& Hajizadeh, N. (2012). Characteristics of effective EFL instructors: Language learners' perceptions. Procedia- Social Behavioural Sciences, 70, 163-173.

Thompson, S., Greer, J., \& Greer, B. (2004). Highly qualified for successful teaching: Characteristics every teacher should possess. Essays in Education, 10 (Summer), N/A. 